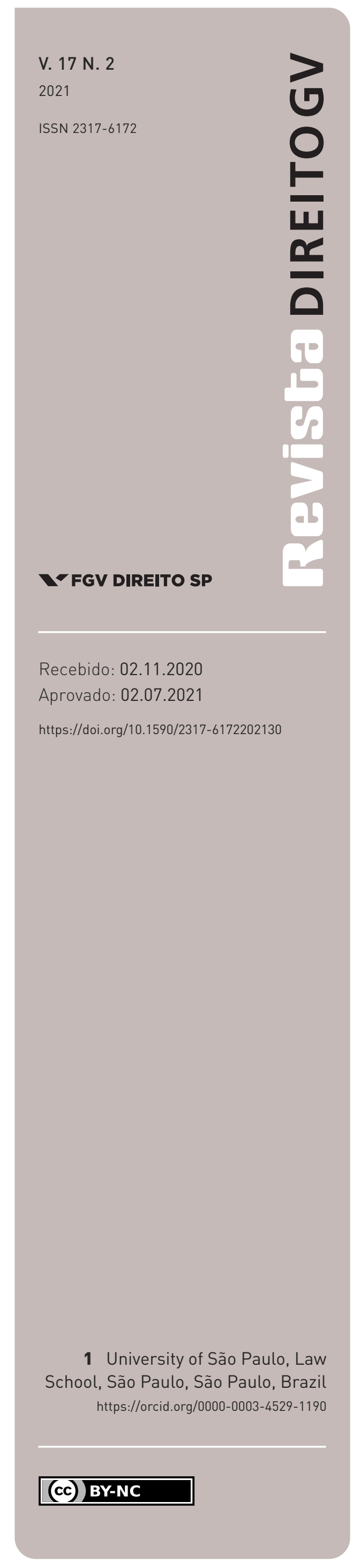

\section{When Institutional Multiplicity Backfires: The Battle Over the Jurisdiction to Prosecute Politicians for Administrative Improbity in Brazil}

QUANDO A MULTIPLICIDADE INSTITUCIONAL SAI PELA CULATRA: A DISPUTA JUDICIAL PELO FORO PARA PROCESSAR POLÍTICOS POR IMPROBIDADE ADMINISTRATIVA

Vivian Pereira Ferreira'

\begin{abstract}
Brazilian Administrative Improbity Act (Law n. 8.429/1992) created a different form of punishment for corrupt behavior and it may be understood as an attempt to introduce institutional multiplicity in the country's legal system. Even though the law has been largely applied and resulted in the imposition of sanctions, it also has limitations: cases often taken several years before being concluded and the recovery of assets has not been substantial overtime. This paper seeks to elucidate some of the reasons why this might have happened. We argue that poor legal design combined with legal implementation problems resulted in delays in final judicial decisions. This paper focuses on a topic that has occupied Brazilian courts for a long time: determining in which jurisdiction should authorities and politicians be tried for administrative improbity. We describe the most prominent Supreme Court's decisions about the theme and try to draw institutional lessons from them, by developing feasible solutions to improve the enforcement of Law n. 8.429/1992.
\end{abstract}

\section{Keywords}

Political corruption; administrative improbity; institutional reform; law enforcement; institutional multiplicity.

\section{Resumo}

A Lei de Improbidade Administrativa - LIA (Lei n. 8.429/1992) criou um novo tipo de punição para casos de corrupção e pode ser compreendida como uma tentativa de promover multiplicidade institucional no ordenamento jurídico. Embora ela venha sendo amplamente aplicada, resultando na imposição de sanções, também tem limitações: demora na resolução dos casos e baixo impacto na recuperação de recursos para o erário. 0 presente artigo investiga alguns dos motivos para isso. Sustenta-se que problemas no texto legal se somaram a dificuldades na aplicação da lei, de modo a dificultar que se alcançassem entendimentos definitivos nessas ações. 0 artigo concentra-se em um problema que por muito tempo ocupou os tribunais brasileiros: determinar em que jurisdição autoridades e políticos devem ser julgados por atos de improbidade administrativa. As decisões mais importantes do Supremo Tribunal Federal (STF) sobre o tema são descritas de forma analítica, de modo a permitir que delas se extraiam algumas lições institucionais, concebendo soluções para melhorar a aplicação da LIA.

\section{Palavras-chave}

Corrupção; improbidade administrativa; reforma institucional; eficácia; multiplicidade institucional. 


\section{INTRODUCTION}

Since Brazil's democratic transition in 1988, the country has been strengthening its accountability ${ }^{1}$ institutions. In the early 1990s, the Brazilian Administrative Improbity Act (Law n. 8.429/1992) was enacted as an attempt to improve the effectiveness of the struggle against corruption. The new piece of legislation established a different form of punishment for corrupt behavior, enhancing institutional multiplicity in the Brazilian legal system.

While the law has been largely applied and ultimately resulted in the imposition of sanctions, cases have accumulated and have often taken several years before reaching conclusion. Recovery of assets has also not been substantial. This paper analyses the enforcement of the Administrative Improbity Act to highlight some of the reasons that might have hindered the success of the reform.

The paper concentrates on a topic that has occupied Brazilian courts for a long time: determining in which jurisdiction should authorities and politicians be tried for administrative improbity. Indeed, the law does not establish the jurisdiction in which cases against elected officials should be filed and tried. This encouraged politicians to raise arguments of procedural fairness and demand that they should be tried either before the Legislative Branch or the Supreme Court, therefore avoiding - or at least postponing - substantial discussions about their alleged illicit behavior.

Drawing on previous qualitative research of the Supreme Court's jurisprudential repository (FERREIRA, 2020), we analyzed its most important decisions about the theme and concluded that poor legal design combined with legal implementation problems delay final judicial decisions. Courts have been debating for years how to interpret the Administrative Improbity Act considering other existing systems of responsibility once confronted with procedural fairness issues. Overly theoretical and unpragmatic judicial debates as well as the absence of a strong precedent system have led to legal uncertainty ultimately undermining the effectiveness of the mechanism. In the face of a rather complex political and institutional reality, the strategy of establishing a new law to promote institutional multiplicity seems to have backfired.

Finally, we explore the institutional lessons learned from these cases and advance possible solutions to improve the law's enforcement. Given that the sheer existence of institutional multiplicity does not guarantee the effectiveness of accountability systems (PRADO and PIMENTA, 2021), we hope that a rich empirical analysis can contribute to develop contextspecific knowledge about the potential and limits of multiplicity in anti-corruption efforts.

1 Accountability may be defined as an assurance that governments and their agents act in a public-regarding manner as they create and implement public policy. As a dynamic process, it may be divided into three different stages: oversight (catching poor performance or malfeasance before it progresses); investigation (uncovering the depth and extent of past malfeasance); and sanctioning (practically holding agents accountable for illicit acts through sanctions) (TAYLOR and BURANELLI, 2007, p. 61-62). 


\section{Administrative ImProbity: ANOTHER Liability Regime fOR CORRUPT BeHAVIOR}

The Administrative Improbity Act was enacted in 1992 among a notorious scandal involving bribes and embezzlement of public funds. At the time, Brazil already had anti-corruption legislation as well as laws that aimed at holding agents accountable for corruption-related misdeeds. Different statutes governed criminal, civil, and administrative liability regimes, covering different conducts, following different procedures, and also imposing different sanctions (PRADO and CORNELIUS, 2020, p. 13). The Act was a reaction to a context in which the public administration faced a credibility crisis and aimed to present the people with a new remedy against malpractices in government (MARQUES NETO and PALMA, 2017, p. 22; SUNDFELD, 2017, p. 229-330).

On several occasions, the exposure of corruption in Brazil has given rise to new anti-corruption initiatives seeking to establish a strong legal framework for accountability. Law $\mathrm{n}$. 8.443/1992, which regulates the Federal Court of Accounts, for example, was enacted while president Fernando Collor de Mello was being impeached. Law n. 8.666/1993, which regulates the bidding process to make it more transparent and accountable, was enacted shortly after a scandal involving a Congressional Budget Committee (FILGUEIRAS and AVRITZER, 2013, p. 223).

The Administrative Improbity Act reflects the understanding that anti-corruption efforts should prohibit a broad range of conducts, target several different agents, and also impose severe sanctions. The law distinguishes three types of illicit behavior: illicit personal enrichment, damage to the public budget, and violation of administrative principles. It presents a non-exhaustive list of acts to illustrate each of these violations, by enabling interpretation regarding specific behaviors and cases. Such rules apply to all sorts of public officials as well as to private agents who have eventually profited from the malfeasance. Conviction may result in fines, loss of assets, full compensation for damages, removal from public office, ban from public bidding processes, disqualification from tax benefits, as well as temporary suspension of political rights.

The new law meant the creation of another accountability regime, an independent mechanism that developed one more institutional path to punish corruption-related behavior (CARSON and PRADO, 2014, p. 18). Institutional reform is traditionally at the core of anti-corruption initiatives ${ }^{2}$ and one of the ways it has been advocated is through the promotion of institutional multiplicity, i.e., allowing a single corrupt act to be monitored and

2 Academic literature has traditionally approached the problem as the result of inefficient institutions or, at least, as something which can be improved through an institutional reform: "a high level of corruption indicates that something is wrong with the State's underlying institutions and incentives" (ROSE-ACKERMAN and PALIFKA, 2016, p. 14). 
prosecuted by multiple institutions, resorting to different areas of the law. As Carson and Prado (2014) have suggested, criminal, civil or administrative law institutions may productively compete among themselves to combat corruption, reducing the chances of failure in detecting and sanctioning illicit activity. Multiplicity may also allow compensation, if one of the institutions fails to perform its functions another may fill its gap. Furthermore, multiplicity may foster collaboration, as more human and financial resources are allocated to the task, or complementarity, by combining different and complementary specialized skills (CARSON and PRADO, 2014, p. 8-9).

However, as Machado and Paschoal (2016) point out, effective institutional cooperation in the prosecution of corruption in Brazil is still rare. Due to the lack of legal requirements, cooperation is mostly based on personal trust and often investigators are reluctant to provide sensitive information to members of other institutions they do not personally know. Collaboration may also suffer from language obstacles (lack of a common vocabulary across different institutions, especially on the technicalities regarding public expenditure) and institutional vanity (those who are known for uncovering major cases of corruption), resulting in delays, which could jeopardize legal effectiveness. Competing institutional efforts to curb corruption may also drain State resources and ultimately result in violation of individual rights as the agent might end up being punished multiple times for one single act (MACHADO, 2019). Therefore, promoting institutional multiplicity is not enough to ensure effective accountability systems.

In order to better understand the Administrative Improbity Act's standing in Brazilian anti-corruption regulation, it is useful to assess how these different liability regimes operate and how they overlap.

Firstly, criminal accountability is regulated by the Criminal Code, which lists crimes such as accepting, demanding, offering or paying bribes, embezzlement, as well as influence peddling. ${ }^{3}$ They may result in harsh punishment, including imprisonment. These felonies are investigated either by the police or the Public Prosecutor's Office, which may press charges before a criminal court. Criminal procedure is based on strict procedural safeguards to ensure the defendant's right to a full defense. It sets a high standard of proof and the prosecution is required to prove its case beyond a reasonable doubt. In criminal matters, certain politicians, and other high-ranking authorities such as Ministers of State, Supreme Court Justices, and the Attorney General are tried before superior courts, which are composed of experienced judges who are also supposedly distant from local political tensions.

Secondly, civil accountability can involve general tort law to ensure reparation for any damage caused. Public and private agents may be responsible for damages to collective and

3 Criminal behavior with electoral impacts, such as buying or selling votes and other frauds, are considered electoral crimes (Law n. 4.737/1965), prosecuted before a subject-specific branch of the Judiciary. 
diffuse interests (Law n. 7.347/1985 - Public Civil Action Law). The public prosecutor's office might conduct a civil investigation to ascertain liability, but lawsuits may also be filed by civil associations, for example. Such cases are prosecuted before lower courts ${ }^{4}$ and the burden of proof might be inverted depending on the circumstances. Accountability might stem not only from malice but also from fault, negligence, recklessness, or incompetence of the defendant. ${ }^{5}$

Thirdly, administrative accountability applies sanctions outside the Judiciary field. A public servant, for instance may be charged with violation of the Public Servants Act (Law n. $8.112 / 1990)$. Individuals and private companies may suffer the imposition of sanctions by the government's direct management structure, by regulatory agencies responsible for sectorial regulation, anti-trust authorities, as well as Courts of Auditors. While administrative procedures are adversarial and must guarantee the defendant's right to a full defense, they are much more flexible regarding the burden of proof standards and so they tend to punish a wider variety of conducts (DA ROS, 2019, p. 1256-1257).

For politicians, accountability may also stem from the Legislative Branch. Parliamentary Commissions of Inquiry (CPIs), for example, have broad investigative powers and may urge the Public Prosecutor's Office to promote civil or criminal liability of those responsible for any harmful act to the treasury. The Congress is also able to prosecute the President, Ministers of State, Supreme Court Justices, as well as the Attorney General for crimes of political responsibility (Law n. 1.079/1950), which can even result in the removal of office (impeachment).

These liability regimes overlap and the same behavior might result in several different procedures. Their outcomes, however, are likely to vary as the requirements for punishment and procedure rules in each one of them are quite different.

$4 \quad$ In Brazil, lower courts are composed of numerous and mostly young and inexperienced judges scattered across the country. New members of the Judiciary are selected through a public contest. Even though candidates must demonstrate previous legal experience, the requirement is simple (3 years) and, as pointed out by Cardoso et al. (2016), can be easily fulfilled with the assistance of friends or relatives who work in law firms and allow the candidates to sign a few petitions and documents over the years while they dedicates their time and efforts to the contest itself. In fact, due to the specificities of such contests, most of the candidates who dispute are newly graduated lawyers from renowned law schools, who meet the economic conditions that enable them to exclusively study.

5 Politicians and public servants' measures are also subject to other civil procedures that protect individual and collective rights. Law n. 4.717/1965 - Law of Popular Action (Lei da Ação Popular) allows any citizen to plead for the annulment or declaration of invalidity of measures harmful to the State's assets. Moreover, the Writ of Mandamus (mandado de segurança) allows individuals to repel illegal acts exercised with abuse of position that threaten or harm clear and perfect individual or collective rights. While these procedures do not allow the Judiciary to impose sanctions, they may be responsible for stopping illicit behavior. The decisions made by authorities may be questioned before the courts in many different civil procedures. 
By creating a new judicial accountability regime to punish corruption-related behavior, the Administrative Improbity Act sought to avoid the major obstacles to the efficiency of the criminal and political accountability systems. It could avert the heavy burden of proof in criminal cases, allowing the prosecution to take place even if the evidence collected did not fulfill the demanding standards of criminal law (ARANTES, 2011). It could also prevent all cases involving high-ranking authorities from being referred to the Legislative or the Supreme Court and avoid the long-lasting controversy over the fact that public prosecutors could investigate corruption cases besides the police, which is more vulnerable to political pressure from the Executive Branch (GIACOMUZZI, 2013, p. 293). ${ }^{6}$

We concede that Brazil has recently witnessed a rise in the effectiveness of the criminal repercussions of corruption. The detection of large schemes of corruption, such as those uncovered by Car Wash Operation, ${ }^{7}$ resulted in the arrest of important political leaders as well as businesspeople. However, it does not mean that administrative improbity cases have ceased to be filed. Car Wash Operation itself has resulted in at least 8 administrative improbity suits against 50 individuals, 16 companies and 1 political party. These suits seek to retrieve R $\$ 14.5$ billion to the treasury (MPF, 2017, p. 22). Both accountability systems are currently combined in the fight against corruption.

The Administrative Improbity Act should presumably provide for a more efficient alternative of accountability than the current criminal and political systems (ARANTES, 2011; GIACOMUZZI, 2013, p. 292). Its results, however, have been relatively disappointing.

\section{The LAW's EFFectiveness: Relatively Disappointing Results}

Like any other anti-corruption law, the outcomes associated with the Administrative Improbity Act might be assessed according to its effectiveness, efficiency, substantial and procedural

6 Currently, criminal investigations in Brazil can be carried out by both the police and the Public Prosecutors' Office, as decided by the STF (RE 593.727, plenary, judged on May 14, 2015). Nevertheless, the debate on the topic has stretched over time, being the center of discussions of a proposed Constitutional Amendment (PEC n. 37), which aimed to limit the investigative powers of the Public Prosecutors' Office in criminal investigations. However, it was rejected by the National Congress on June 25, 2013.

See http://www.camara.gov.br/proposicoesWeb/fichadetramitacao?idProposicao=507965 and http://g1. globo.com/politica/pec-37 -what-and / platb /. Accessed on: December 12, 2019.

The full content of PEC n. 37 is available at: https: / www.camara.leg.br/proposicoesWeb/fichadetramitacao?idProposicao $=507965$.

7 Car Wash Operation is considered Latin America's largest corruption scandall to date. Since 2004, investigations revealed collusion between construction companies and state officials in Brazil and 11 other countries, uncovering hundreds of millions of dollars paid in bribes and billions of dollars stolen from state funds. 
fairness, as well as legitimacy (DAVIS, 2019, p. 10). In other words, its evaluation depends on ascertaining how well it achieves its objectives relative to the associated costs, if those costs are distributed appropriately, if the process is ensured and finally if people perceive the law as legitimate.

Surely, cases must be brought to courts, guilty defendants must be convicted, and appropriate punishment must be rendered. ${ }^{8}$ Since the enactment of Law n. 8.429/1992, administrative improbity cases were profusely brought to courts. By 2009, 38\% of the cities in the State of São Paulo (247) had already had their mayors prosecuted for administrative improbity at least once (ARANTES, 2009, p. 93). According to Barbão and Oliveira (2018, p. 27-28), by 2015 there were more than 36,000 active administrative cases in the country. In June 2021, the Superior Court of Justice search engine displayed 5,778 individual decisions and 48,071 collegiate decisions for the term "administrative improbity".

Investigations continue to grow and the number of lawsuits in Brazil has expanded throughout the years. The Federal Public Prosecutors' Office, for example, registered a 62\% surge in charges pressed between 2014 and 2017, resulting in 2,371 new lawsuits in 2017 (MPF, 2018). These figures do not account for the percentage of cases that have been discovered and prosecuted in the whole universe of actual unlawful conduct. However, they certainly allow us to conclude that the law is being enforced.

Interestingly, administrative improbity cases tend to be ruled in favor of the plaintiff. Statistical studies reveal that cases are mostly filed by the Public Prosecutors' Office (ALVES DA SILVA and HENRIQUES DA COSTA, 2011, p. 51; GOMES JUNIOR, 2015, p. 25-26); the defendants are mostly elected officials, especially mayors (ALVES DA SILVA and HENRIQUES DA COSTA, 2011, p. 53; BARBÃO and OLIVEIRA, 2018, p. 30; CNJ, 2012, p. 14; GOMES JUNIOR, 2015, p. 17). Most cases are ruled in favor of the plaintiff: $48.87 \%$ of all

Effectively condemning wrongful conduct expresses moral condemnation, affirming that corruption is intolerable. It also allows compensation for the victims for any harm that has previously occurred. Finally, it prevents corrupt behavior, either by making it literally impossible to occur (incapacitation), by persuading agents not to engage in corrupt behavior (persuasion), or by creating incentives for them to refrain from it (deterrence) (DAVIS, 2019, p. 7). Anti-corruption legislation is primarily based on the deterrence literature, assuming that people tend to respond to incentives. Therefore, impunity is a major concern when it comes to corruption, especially if high-level officials or powerful foreign actors are involved, by considering their prominent position for undermining legal institutions' enforcing capabilities (DAVIS, 2019, p. 6-7). The reasons why people obey the law have been widely debated in the social sciences. Some authors point out that individual motivation to cooperate with others and respect for the rules established by the community stem not only from the desire to avoid sanctions or receive rewards, but also depend on the perception of the legitimacy of the authority that creates the rules, as well as the participation, as process and transparency could be considered to be crucial elements of legal enforcement (TYLER, 2006). 
cases analyzed by Alves da Silva and Henriques da Costa (2011, p. 59). Another $14.95 \%$ of cases were partially upheld and only $29.58 \%$ were in favor of the defendant. According to a more recent report, $77.26 \%$ of the judicial decisions in administrative improbity cases were favorable to the Federal Public Prosecutor's Office (MPF, 2017, p. 89). Therefore, not only is the law being enforced, but also convinctions are being rendered.

However, the number of convictions cannot be set as the only criteria for the evaluation of the success of the law's enforcement. When a conviction is the sole parameter of effectiveness, all other outcomes are considered as indicators of ineffectiveness, even if other outcomes were eventually more appropriate in a specific case, given the collected facts and evidence (MACHADO, 2015, p. 191). An acquittal would then be perceived as a decision that prevents the Judiciary from reaching its primary purpose (convicting the corrupt), disregarding the circumstances.

Effectiveness can also be assessed in terms of length of trials, as well as capability to recover values for the treasury - and in that regard, the Administrative Improbity Act could be criticized. While convictions registered between 2006 and 2016 amount to approximately R $\$ 1.9$ billion, the money recovered corresponds to roughly $\mathrm{R} \$ 2.7$ million, $0.1 \%$ of the total in convictions (BARBÃO and OLIVEIRA, 2018, p. 30). Even considering the possibility that the database contains errors and omissions, the information points to serious obstacles in recovering money.

Furthermore, cases often take a long time before they reach a definite conclusion (ARANTES, 2011, MESICIC, 2012, PRADO and CARSON, 2014, p. 18-19). They have been accumulating and lingering over the years and since 2013, the National Council of Justice (Conselho Nacional de Justiça - CNJ) has been establishing a target for courts, determining the number of administrative improbity cases that ought to be decided each year, in order to reduce the large backlog of undecided cases. ${ }^{9}$

The Administrative Improbity Act has so far had limited effectiveness: the law is being used and is generating sanctions, but it may be questioned in terms of length of the trials and effective recovery of assets. Its enforcement also demands considerable public investments, raising doubts about its efficiency. Long-lasting cases that stretch on for several years ${ }^{10}$ also have consequences on the individual rights of defendants. It may raise concerns about fairness as they remain under the scrutiny of the Justice System for years, considering all the

9 The Judiciary's trial goals for recent years may be found at: http: / /www.cnj.jus.br/gestao-e-planejamento $/ \mathrm{metas} / \mathrm{metas}$-de-exercicios-anteriores?id $=17513$.

10 The National Registry of Convictions for the Administrative Improbity Act, held by the National Council of Justice (CNJ), indicates that administrative improbity cases today take more than six years on average to be decided (ABJ, 2017). 
associated reputational damages especially experienced by companies and elected officials (WARDE, 2018; ARANTES, 2009, p. 59). ${ }^{11}$

The National Council of Justice's determination for the Judiciary to accelerate decisions on such cases is not a definite solution for the problem, as it depends on other limits imposed by Brazilian institutions and incentives. Judicial ineffectiveness is often attributed to structural problems in the Judiciary, which can be divided into two different categories (ARANTES, 2011, p. 198; POWER and TAYLOR, 2011; MOISÉS, 2019):

(i) Factors leading to slowness in reaching results: procedural laws which allow several appeals; an excessive number of cases / appeals have to be tried in high courts, resulting in accumulation of cases in stock and delays in final decisions;

(ii) Factors of insufficiency in the eventually reached results: excessively formalistic processes that allow immoderate questioning about the legality of procedures adopted during investigation, procedural rules that impose a heavy burden of proof; judicial corruption.

Such problems concerning the Judiciary impair all sorts of processes of judicial accountability and indeed problems in the legal implementation seem to have played an important role in the delay of final decisions of administrative improbity cases. But the relative ineffectiveness of the Administrative Improbity Act was aggravated by a legal design problem.

\section{Legal Design: The Lack of Clear Explicit Jurisdiction Provisions}

The Administrative Improbity Act has long been debated and criticized by Brazilian legal scholars for its general vagueness and lack of legal definitions (SUNDFELD, 2017; MARQUES NETO and PALMA, 2017; NEISSER, 2018). In some respects poor legal design may have contributed to hinder the law's effectiveness by creating conditions for these cases to extend in time.

A closer look at the enforcement of the Administrative Improbity Act points to a lack of relevant procedural provisions. The law created a new independent accountability regime, but it was not clear how the different accountability systems should be coordinated in practice.

The Administrative Improbity Act is key to both the empowerment of the Public Prosecutors' Office and the judicialization of politics in Brazil. After interviewing several prosecutors, Arantes (2009, p. 59) pointed out that these lawsuits have a crucial feature: they are effective, but their "waves" spread and can seriouly compromise the image and reputation of elected officials. Prosecutors admit that the effectiveness of their administrative improbity cases is mainly political, which means that the sheer existence of the lawsuit already has an important effect, regardless of its outcome (ARANTES, 2009). 
The law also created a new hybrid procedure, with civil and criminal procedural features. ${ }^{12}$ However, while it did not explicitly provide for the procedural safeguards from the criminal sphere it also did not stress that they are inapplicable. This left a lot of room for discussion, leading defendants to raise questions about procedural fairness.

A recent study mapped the main legal arguments made at the Supreme Court and the Superior Court of Justice in administrative improbity cases and showed that in general (105 out of 164 analyzed cases), the courts discussed procedural issues exclusively. ${ }^{13}$ The study also revealed that some of the concerns regarding procedural fairness seemed justified as the law's enforcement has progressively created a series of presumptions that end up reverting the burden of proof to the disadvantage of the defendant (FERREIRA, 2020).

The most evident example of this situation consists of the decisions in which the agent's mens rea - required for punishment for administrative improbity - is derived from the presumption that the agent was aware to be acting against the law, disregarding circumstances or motives that could eventually justify the behavior. In some cases, the agent was also convicted of causing losses to the public treasury for not complying with bidding procedures, but the actual amount of the loss was never determined. Finally, while processing an administrative improbity claim should depend on the assessment of the plausibility of the accusation, law-

12 The statute refers to the Code of Civil Procedure - when dealing with hypotheses of procedural dishonesty and the procedure for restraint of assets of defendants - and to the Criminal Procedure Code when establishing the rules for testifying and questioning witnesses. The procedure resembles the criminal one: it provides, for example, for a prior decision on the possibility of processing the claim (art. 17, $\S 8)$. In addition, in Chapter 4 ("the criminal provisions"), the law determines that punishments such as removal from office and temporary suspension of political rights are only effective after the final and unappealable decision. In contrast, the language used in the law is similar to the civil procedure, concerning civil appeals for example.

13 The doctoral unpublished research was conducted at University of São Paulo between 2017 and 2020. It focused on the enforcement of Law n. 8.429/92 and investigated how courts contributed to building the new liability system applicable to politicians in Brazil. Analyzing the decision-making process over time, it described the tensions and dynamics of the different institutions involved in the law's enforcement and assessed the role of the Judiciary in this process according to its ability to create legal certainty.

In total, 164 decisions of the Supreme Court (STF) and the Superior Court of Justice (STJ) were analyzed. Cases were selected for their ability to convey legal theses that would be applied to other similar cases according to Brazilian procedural law - repetitive appeals (recursos repetitivos) from the STJ, appeals with broad repercussion (repercussão geral) from the STF - as well as the fact that they were published in the court's bulletins as innovative or relevant decisions. The qualitative analysis conducted did not intend to generate statistical results, but to portray the main theoretical discussions that had been held on the theme of administrative improbity and the responsibilities of different institutions in the judicial dynamic. 
suits are frequently proceeded on the presumption that it is the public interest to prosecute corruption if there is the slightest chance it might have happened (FERREIRA, 2020).

These concerns about potential violations of due process combined with aprehension regarding the lack of accountability of judges and public prosecutors raise important legitimacy issues. The Public Prosecutor's Office is the most prominent plaintiff in administrative improbity cases but it is rarely in the position of defendant. Judges are also uncommon defendants. The typical defendants are politicians, especially mayors (ALVES DA SILVA and HENRIQUES DA COSTA, 2011, p. 53; BARBÃO and OLIVEIRA, 2018, p. 30; CNJ, 2012, p. 14; GOMES JUNIOR, 2015, p. 17).

As common defendants, politicians have raised a discussion about due process that has occupied Brazilian courts for a long time: defining who should be responsible for deciding administrative improbity charges against them. There are two different ways this discussion was conducted. First, there is the problem of defining whether politicians can be tried before the Judicial branch or if their cases should be referred to the Legislative branch. Then, there is the matter of whether they can be prosecuted before lower courts or if their cases should be referred to higher courts.

Indeed, administrative improbity cases often involve behaviors that could also be considered crimes of political responsibility, which are prohibited by Law n. 1.079/1950 and are prosecuted before the Legislative. The problem could thus be framed as a separation of powers issue, as well as of potential violation of the ne bis in idem principle as a person could be tried twice for the same illicit act. Allowing such cases to be prosecuted exclusively by the Legislative would mean exposing them to political will, circumstantial agreements between political parties, as well as potential ineffectiveness.

It is important to consider that the Administrative Improbity Act claims that its sanctions are independent of other civil, criminal, or administrative legal repercussions. However, this ordinary provision does not account for arising coordination problems as the legislation is enforced, such as whether one procedure should be suspended while claims are prosecuted in another jurisdiction, the circumstances in which proofs can be shared by different prosecuting authorities, or whether judges should consider the sanctions already imposed by other jurisdictions when judging the same illicit behavior. While this problem is not necessarily internal to the Administrative Improbity Act, the lack of explicit rules on how to coordinate different institutions responsible for advancing accountability has led the Judiciary to an intense debate on how to interpret the Administrative Improbity Act considering other existing systems of responsibility. ${ }^{14}$

14 This is an omission which demands challenging legal solutions, which take into account the need for legal effectiveness and the respect for due process, avoiding bis in idem. For more information about this topic, check Machado (2019). 
Furthermore, unclear procedural provisions allowed administrative improbity cases to be placed in a grey area between civil and criminal, raising doubts about whether they should be prosecuted before lower courts, as in civil lawsuits, or before higher courts, as in criminal lawsuits. The special jurisdiction rule is a typical prerogative of criminal law, designed to ensure the trial's impartiality as it moves cases away from undue local political pressures. The rule derives from a legitimate concern with the politicization of justice, intended at preventing routine political decisions from being continually challenged by the opposition in the Judiciary. Criminal lawsuits might be used as instruments to advance or stop certain policies, to ruin political reputations, as well as to bring prestige and recognition to prosecutors and judges as moral strongholds of society. Furthermore, being obliged to defend themselves in several courts scattered across the country could keep government members in a permanent and unproductive state of alertness and ultimately fear (FERREIRA, 2020, p. 155-198).

On the other hand, the special jurisdiction rule is considered a major obstacle to the efficiency of the criminal accountability system, as an excessive number of cases involving elected officials end up in higher courts, creating a backlog. It results in a legitimate concern with impunity: overburdened courts lack the institutional capacity to expediently adjudicate a great number of cases. Moreover, few public prosecutors are allocated to work at the Supreme Court level, and they would struggle to identify, investigate and combat crimes in the whole country working from the capital. Finally, even in higher courts, political will can have an important effect on the cases. All these problems have led special jurisdiction rules to be regarded not as a prerogative, but as a privilege of the powerful and well connected (FERREIRA, 2020, p. 155-198).

Therefore, allowing politicians to be tried and prosecuted only before the Legislative or the higher courts could make the new liability system as ineffective as the current ones. But explicitly denying this fact would probably hamper the bill from being approved by the legislature. The silence about the issue has resulted in endless judicial debate about procedural fairness.

\section{Legal Implementation: Brazilian Courts' Struggle with Defining Who Can Prosecute Politicians}

The jurisdiction in which different sorts of politicians should be tried in cases of administrative improbity is not explicitly defined by the law. Even though the Administrative Improbity Act aimed to bypass some of the rules considered to impair the effectiveness of the political and the criminal accountability systems, the bill did not explicitly determine that such cases should be prosecuted before judicial lower courts, resulting in years of judicial controversy. The reasons why the drafters of the legislation did not avoid legal uncertainty are unknown, considering the lack of historical research on the matter, but they may be related to lack of consensus in the legislative process as well as to a deliberate political strategy. In any case, 
explicitly denying politicians to be tried before the legislative branch or higher courts would probably hinder the approval of the bill.

The idea that political authorities should not be prosecuted and tried before lower courts is long-standing. Indeed, the country's first Republican Constitution (1891) provided that senators and deputies could not be criminally prosecuted without authorization from their fellow Congress members (art. 20), that the president should be prosecuted and judged by the Senate for criminal offenses or crimes of political responsibility (art. 33), and that ministers of the federal government could only be tried before the Supreme Court in criminal matters (art. 52, §2). ${ }^{15}$

Defining the appropriate jurisdiction to prosecute and decide cases involving different sorts of political authorities has considerably occupied the Supreme Court's agenda over time (FERREIRA, 2020). Using the court's jurisprudential repository as a source of information, a research conducted in 2019 identified decisions relating to administrative improbity that either conveyed binding legal ruling (repercussão geral) or were considered relevant to be published in the courts' "jurisprudence bulletin". ${ }^{16}$ More than half of the resulting cases (17 out of 31 ) were related to the special jurisdiction problem (FERREIRA, 2020, p. 157).

Instead of analyzing the Administrative Improbity Act as a new institutional path that should be coordinated with other accountability systems in place, parties and judges framed the problem as a matter of defining whether the law should be considered civil, administrative, or criminal to further establish the procedural safeguards applicable to such cases. A closer analysis of the most prominent among such decisions ${ }^{\mathbf{1 7}}$ allows a better understanding of the dispute.

It all began with an administrative improbity case brought to the Supreme Court against a high-ranking authority of the federal government (STF, Complaint n. 2.138, plenary, judged on June 13, 2007). The Chief Minister of the Department of Strategic Affairs of the Presidency was accused of unduly using an aircraft of the Brazilian air force for private use in a holiday.

15 Available at: http://www.planalto.gov.br/ccivil_03/Constituicao/Constituicao91.htm.

16 The results were obtained through the Supreme Court's search mechanism, using the expression "improbidade prox 1 administrativa" - the broadest possible search term, in order to include all possible cases of administrative improbity, avoiding theme-related terms distortions. The "PROX1" connector allows to locate only decisions in which the terms "improbity" and "administrative" appear together (FERREIRA, 2020, p. 94).

17 Cases were considered prominent if they promoted robust debates among justices, lengthy votes and justification, as well as a tendency to be referred to in latter cases. 
The case was brought by the Federal Public Prosecutor's Office to the Federal District lower court resulting in the defendant's conviction. At the time, the General Attorney appealed to the Supreme Court on behalf of the minister, arguing that the acts attributed to him were not administrative improbity but potential crimes of political responsibility, established in Law n. 1.079/1950, which is why the court who had decided the case lacked jurisdiction to do so. The trial at the Supreme Court started in 2002, but it took almost five years to be decided.

In the first trial session, the first five votes accepted the argument according to which high-ranking authorities were already subject to the liability regime provided for in Law $\mathrm{n}$. $1.079 / 1950$ (which defines the crimes of political responsibility, prosecuted before the legislative branch), and therefore could not be submitted simultaneously to the provisions of Law n. 8.429/1992 without offending the ne bis in idem principle. Justices claimed that both laws regulated the same behavior. They also disagreed that a Minister of State could be tried before a lower court. For them, high authorities differ from public servants in general and must have special treatment to guarantee the free exercise of their political function; the risks and complexities of the decisions with which they are involved should not be subject to the same paradigms that prevail in routine administrative life. They thus ruled in favor of the extinction of the ongoing lawsuit.

These votes did not go uncontested and were resisted in the Supreme Court, as the other six votes were presented in the following trial sessions, held between 2005 and 2007. Nevertheless, the argument concerning which politicians may not be submitted to two different and overlapping liability regimes prevailed in this specific case.

The result reflected a momentary understanding and it was only achieved because the new members of the Supreme Court were unable to change those five votes of 2002 cast by justices who had retired by the time the trial was concluded. The decision also had limited effect as it did not automatically apply to other cases and referred specifically to a Minister of State of the federal government.

The legal argument, however, became widely used in politicians' defensive arguments in administrative improbity cases, as pointed out by Paulo Eduardo Alves da Silva and Susana Henriques da Costa (2011, p. 56-58). Mayors, governors, and congressmen, who were subject to specific normative arrangements, claimed that their situation was similar to the one previously decided by the Supreme Court, forcing it to decide the issue several times.

The matter was reconsidered in a similar case involving a former Minister of Transport in the federal government, accused of irregularly releasing writs of payment - precatórios (STF, AgRg Pet. 3.240, plenary, judged on May 10, 2018). The lawsuit was filed before the lower court, which initially authorized the breach of the defendants' banking secrecy. An interlocutory appeal was filled against this decision referring the matter to the Regional Court, which declined its jurisdiction and referred the case to the Supreme Court.

In this second case, by a large majority, the court established the possibility of submitting all political authorities, except the president, to both liability regimes: the one provided in 
Law 1.079/1950 and the other in Law 8.429/1992. The court further established that even though they referred to similar behaviors, both laws were distinct from each other and both liability regimes were applicable, even if a single fact could potentially instigate two different processes of accountability.

The possibility of prosecuting politicians both for crimes of responsibility and for administrative improbity was recently reaffirmed by the Supreme Court (STF, RE 976.566, plenary, judged on September 19, 2019). The case related to the mayor of Eldorado dos Carajás, a small city in the Northwest of Pará accused of defrauding the investment of public money destined for elementary education. He was convicted by a local court and the sentence was upheld by the State Court of Pará after an appeal. The mayor further appealed to the Supreme Court, claiming that the Administrative Improbity Act did not apply to the case, as mayors could only be held responsible for crimes of political responsibility processed before the legislative branch.

In a unanimous decision, the Supreme Court dismissed the appeal, by stating that regardless of whether the mayors' actions could be classified as a criminal offense or as a crime of political responsibility, the liability regime provided for in Law n. 8.429/1992 is autonomous and must be conducted before a different jurisdiction. Due to its distinct legal nature, it could not entail bis in idem. In this case, the argument was binding and should be considered by all other courts in the country when deciding on similar cases.

While the Supreme Court addressed the matter, perplexity with submitting top-level politicians accused of administrative improbity to the decisions of lower courts had also been addressed by the legislature. On December 24, 2002, Congress enacted Law n. 10.628/2002, which amended article 84 of the Criminal Procedure Code to include a new provision. It established that cases of administrative improbity involving politicians should be brought before the same court legally assigned to prosecute and judge them in criminal matters, as they perform public functions. The law, therefore, explicitly provided that lower courts could not process administrative improbity cases filed against politicians, such as in criminal matters.

Judges and public prosecutors deemed the provision that explicitly withdrew their power to try high-ranking authorities unconstitutional. The national association of public prosecutors (Associação Nacional dos Membros do Ministério Público - CONAMP) and the national association of Brazilian judges (Associação dos Magistrados do Brasil - AMB) challenged the constitutionality of Law n. 10.628/2002, claiming that special jurisdiction rules were expressly and exhaustively established in the Constitution and could not be extended by the legislature (STF, ADI 2.797 and 2.860, plenary, judged on September 15, 2005).

It took the court almost three years to reach a decision. During that time, the debate about the appropriate jurisdiction responsible for processing several claims from different parts of the country led to a series of complaints in the Supreme Court aimed at solving the problem in specific cases. It was only in 2005, that the Supreme Court held Law n. $10.628 / 2002$ unconstitutional, eliminating the possibility that politicians could invoke the 
criminal procedural prerogative to be prosecuted and tried by the higher courts in cases of administrative improbity.

In the decision, some of the justices asserted that the Administrative Improbity Act extrapolates the domains of civil law and imposes harsh sanctions that imply restrictions on fundamental rights. For that reason, the same logic that rules the criminal law - in which the special jurisdiction rule is a due process requirement - would also be applicable to them. The special jurisdiction rule was regarded as a protection of the free exercise of public and political functions, in other words, a procedural guarantee of equality.

Most justices, however, asserted that the sanctions provided for in Law 8.429/1992 are not comparable to criminal sanctions and that special jurisdiction rules are constitutionally restricted to criminal matters. They also highlighted article 37 of the Constitution, according to which acts of administrative improbity will result in several sanctions, "in the form and gradation provided by law, not excluding criminal sanctions". For this reason, they argued that if administrative improbity cases are not criminal cases, they should be treated as civil lawsuits.

Between the enactment of Law 10.628/2002 and the decision that declared it to be unconstitutional several administrative improbity cases had already been tried before lower courts. To avoid their annulment, the Supreme Court decided that the declaration of unconstitutionality would be applied from September 15, 2005 onward. The decision preserved the validity of lower courts' decisions and determined that cases that had not yet been tried would be sent to the appropriate jurisdiction. It ultimately led several administrative improbity cases to be decided by local judges.

The fact that the court did not manage to clearly and promptly establish the procedural provisions applicable to administrative improbity cases allowed litigants all over the country to choose between one or another argument previously supported by one of the Supreme Courts' justice. Filling appeals to the court, they managed to suspend ongoing lawsuits and investigations and extend the duration of cases over the interpretation of the jurisdiction rule.

Only recently Supreme Court has clearly stated that administrative improbity cases should indeed be tried before lower courts. Thus, a huge number of prosecutors across the country are now capable of prosecuting authorities, without the limitations of the special jurisdiction rules applicable to criminal offenses, or without the need for specific political arrangements on which the prosecution of crimes of political responsibility by the Legislative depend (ARANTES, 2009, p. 58). The outcome implies significant empowerment of anticorruption authorities and could assist to expedite future cases.

It is still unlikely that due process allegations against the Administrative Improbity Act will simply cease. So far, Supreme Court decisions have only dismissed that there could be a problem in the fact that both liability regimes - criminal law and administrative improbity - might operate in parallel. It did not adequately address other due process problems, such 
as the adequate distribution of the burden of proof or potential bis in idem if one single act is punished by several jurisdictions. Prosecuted politicians will likely continue to use these due process arguments in future cases, by trying to raise new legal arguments related to the burden of proof or questioning the proportionality of imposed sanctions. New discussions about the protection of individual rights seem almost inevitable (NEISSER, 2018; MACHADO, 2015) and in the absence of clear legal procedural provisions, the Judiciary will presumably remain in the center of such disputes. ${ }^{18}$

\section{Prolonged Legal Uncertainty and Legal Formalism as Obstacles to EFFECTIVENESS}

The Administrative Improbity Act introduced institutional multiplicity as a means for trying to expedite corruption prosecution in the country, however, it lacked clear provisions regarding the jurisdiction in which different sorts of politicians should be tried in such cases. It took more than ten years for the Supreme Court ${ }^{19}$ and the Superior Court of Justice ${ }^{20}$ to finally establish (i) that administrative improbity cases could run parallel to other accountability processes similar to the one provided in Law n. 1.079/1950; and (ii) that the procedure provided in Law n. 8.429/1992 is not criminal, referring the cases to lower courts.

The institutional multiplicity strategy did not result in greater effectiveness and expediency for corruption punishment at the beginning. The lack of clear legal provisions regarding jurisdiction rules allowed defendants to file appeals and suspend ongoing cases to question where they should be prosecuted, based on arguments of procedural fairness. Immersed in a rather complex political and institutional reality, with overlapping sanctions applied by different institutions and particular normative arrangements for different types of political authorities, courts could not respond in a timely and effective manner to the problems posed by the legal innovation.

It is important to bear in mind that the cases described in this article were decided in multiple trial sessions over several years, sometimes simultaneously, leading to the existence of different precedents that resulted in legal uncertainty. Also, the Brazilian Supreme Court does not deliberate. Justices rarely reformulate their positions or votes (SILVA, 2009; MENDES, 2010)

While the Administrative Improbity Act explicitly recognizes the independence of its sanctions vis-à-vis other administrative, civil and criminal sanctions (article 12), the statute does not establish the criteria for the coordination of the different institutions responsible for advancing accountability, an omission which will demand challenging legal solutions, which take into account both the need for legal effectiveness and the respect for due process, avoiding bis in idem. On the topic, see Machado (2019). STF, ADI 2.797; ADI 2.860, plenary, judged on September 15, 2005. STJ, Rcl, n. 2.723/SP, special section, judged on October 15, 2008. 
and the votes are often read in the trial sessions, with no debate and no concern for addressing issues raised by other justices. Thus, a Supreme Court Decision does not convey a single institutional opinion, and different positions are articulated in votes cast by an apparent majority.

As a result, the legal reasons for the court's decisions are neither clear nor objective. It is, therefore, very difficult to determine the ratio decidendi in each case (VOJVODIC, MACHADO and CARDOSO, 2009), which also hampers litigants to predict the chances of a certain understanding to be applied to future cases. It is considerably easier for them to continue to dispute the application of selected precedents to individual cases.

The cases previously described also reveal that Brazilian courts have tended to be overly concerned with the "legal nature" of the matters under dispute. Indeed, justices have tried to classify the new liability regime according to other existing ones, trying differentiate them. Administrative improbity has been compared to ordinary criminal offenses, to crimes of political responsibility, as well as to other civil illicit acts.

The quest for the "legal nature" of administrative improbity, with the aim of classifying it between distinct and supposedly hermetic areas of the law, could probably be considered natural in a formalist legal culture, in which legal education is traditionally committed to the separation between private and public law, as well as criminal, labor, civil and commercial law (MALDONADO, 2012, p. 117-118). It may also have been reinforced by the fact that Law $n$. $8.429 / 1992$ did not clearly establish its procedural rules, including the jurisdiction in which cases should be tried, leading defendants to argue that other existing provisions were applicable to their specific cases by analogy.

To classify legal provisions as belonging to a particular area of law, one must assume that there is an essential distinction between them. It could be assumed, for example, that criminal law is designed to protect the most fundamental values of society, relating to dignity, ethics, and ensuring social order, while civil law protects private interests and focuses on repairing damages caused to individuals. Administrative law, in turn, could be assumed as designed to establish a more flexible liability regime aimed at organizing and structuring the country's public administration as well as its economy (DA ROS, 2019, p. 1256-1257).

The development of different accountability systems considerably challenges this ontological distinction. Civil liability for environmental damages, related to the whole of society and not to one single individual, places civil liability not as a private matter, but as a social and collective interest. In criminal law, the possibility that the accused might repair the damage caused to the victim implies that the latter's private interests are also considered in this area of the law. This type of classification has been increasingly challenged worldwide, given the complexity of the problems that modern legal systems face (PÜSCHEL and MACHADO, 2006, p. 22).

The type of sanction and its purpose is another criterion traditionally referred to draw a formal distinction between different areas of the law. Civil law is usually characterized as focused on damages while criminal law is associated with punishment and retribution 
(PÜSCHEL and MACHADO, 2006, p. 4-5). Such distinction, however, is progressively less able to effectively describe reality. On the one hand, reparation of damages has been increasingly embraced by the criminal system: if defendants repair the damage the sentence might be mitigated; reparatory agreements might eliminate punishment completely. On the other hand, moral damages in civil liability cases are often assessed with a punitive purpose (PÜSCHEL and MACHADO, 2006, p. 5-14).

The attempt to distinguish the legal nature of different liability regimes - criminal, administrative, and civil - and then to try to fit the Administrative Improbity Act in one of them is problematic. This problem arises because the boundaries between such paradigms are mobile and seem to shift over time as we witness the construction of accountability theories based on a notion of risk that do not fit with one single area of the law (PÜSCHEL and MACHADO, 2006, p. 19-21).

Legal formalism has therefore played an important role in preventing Brazilian courts from responding in a fast and pragmatic manner to questions of procedural fairness that arise from the implementation of Law n. 8.429/1992. Prolonged legal uncertainty has resulted in countless appeals from defendants all over the country to the Supreme Court. The new accountability regime had its effectiveness at least temporarily undermined.

The Supreme Court's recent decision establishing that administrative improbity cases should indeed be tried before lower courts will likely expedite prosecution in future cases. Still, concearns about potential violations of due process in administrative improbity cases should not be entirely dismissed. The response of Brazilian courts so far is unlikely to cease further allegations of procedural fairness regarding other aspects of the statute, especially since these cases tend to involve elected politicians and the accountability of the Judiciary and the Public Prosecutors' Office is still weak.

\section{In Search of Substantive, Context-Specific Solutions}

Implementation of the Administrative Improbity Act in Brazil has been challenged both by a legal design problem - the lack of procedural certainty - and by courts' inability, within a complex political and institutional reality, to respond timely and effectively to arguments of procedural fairness raised by defendants. Prolonged legal uncertainty has undermined effectiveness of the new legal mechanism.

During such judicial debates, parties and courts took a formalistic legal approach as they tended to deal with legal innovation as a matter of adequately fitting the new liability regime into existing categories of distinct and supposedly hermetic areas of legal theory. The solutions so far encountered on these grounds are hardly capable of terminating procedural fairness allegations, which may continue to be raised regarding other aspects of the statute. Affirming that administrative improbity cases should not be treated as criminal cases does not explain how other procedural issues should be decided in the future. 
Productive institutional anti-corruption reform requires multiple institutions operating against corruption instead of creating endless debates about due process and procedural fairness. Indeed, as Prado and Pimenta point out (2021), the sheer existence of multiplicity does not guarantee enhancement of accountability systems; it largely depends on the context in which multiplicity is immersed and the system in which it is operating.

As previously stated, the special jurisdiction rule for political authorities derives from a legitimate concern that political decisions might be continually challenged by the opposition in the Judiciary and it aims at ensuring that the trial does not occur under local political pressures. However, the concentration of lawsuits in the Supreme Court raises concerns with the institutional capacity of the court to deal with cases from all over the country, as well as with the possibility of capture of controlling authorities. The problem of defining the jurisdiction that should be responsible for deciding administrative improbity cases against different political authorities could have been solved by a relatively simple legislative reform. Such reform would have productively shifted debates and efforts to the substantive problems created by Law n. 8.429/1992: how to avoid politicians' trials in a politically charged atmosphere while also avoiding that such cases are referred to the Supreme Court? How to make sure that one single misdeed is punished proportionally, even though it may be prosecuted by several different jurisdictions?

One possible solution would be to remove cases from their natural territorial jurisdiction but not refer them to the Supreme Court. Territorial jurisdiction is the rule in Brazil, but there are exceptions. For example, felonies committed against civilian lives are tried before a popular jury, but Brazilian law already admits, in cases of doubt about the impartiality of the jury or to ensure the security of the accused, the case to be tried in a different region, where those problems do not exist (Criminal Procedure Code, art. 427 -desaforamento).

Another interesting example might be drawn from tax law. The Brazilian Federal Revenue Office (Receita Federal do Brasil) has specialized court divisions (varas especializadas) which are not connected to the place where legal tax violation has occurred. They are themespecific, i.e., responsible for adjudicating cases related to certain specific taxes. This organization is interesting as the applicable rules are federal, and the complexity of taxes demand specialization. Furthermore, procedures are entirely electronic, dismissing the need for parties to personally attend courts (Federal Decree n. 70.235/1972, on tax administrative procedures).

In many states, the Brazilian Judiciary already specialized court divisions for dealing with legal matters that affect the treasury and the public administration (varas da fazenda pública). ${ }^{21} \mathrm{Also}$, the country has recently experienced considerable developments in its electronic

21 These court divisions prosecute civil cases involving the State, public companies, entities and foundations, as plaintiffs or as defendants. They are charged with trying public civil actions, administrative impropriety 
legal procedures. The Law n. 8.429/1992 could be reformed to allow defendants to petition for their cases to be tried before one of these specialized court divisions in another region if they feel that their natural jurisdiction is biased. This would allow not only withdrawing cases from undue local political pressures, but also avoiding the concentration of lawsuits against politicians in the Supreme Court - thus leading judges throughout the country to decide cases and make the capture of the authorities unlikely. This could assist overcoming formalistic debates over the civil or criminal nature of administrative improbity, by creating an institutional mechanism that could not only make anti-corruption efforts more effective and expedient but also less questionable in terms of securing due process and individual rights to defendants.

The concerns about the violation of the ne bis in idem principle that prohibits double punishment, due to the possible accumulation of civil, criminal, and administrative are more complex to be solved (MACHADO, 2015). As pointed out by Teixeira, Estellita and Cavalli (2018), anyone who offends the law must be properly punished, but overlapping sanctions might result in disproportional individual burden and is not a natural trait of the legal system. This burden has also recently been recognized by the European Union Court of Justice about sanctions provided for in administrative law and criminal law (ESTELLITA and CAVALI, 2018).

The imposition of several sanctions of different kinds on the same set of fact stems from an artificial boundary between different areas of the law. Acknowledging and addressing it could ensure proportional State reaction to illicit behavior, as well as contribute to a more transparent, integrated and less costly sanctioning policy (LOBO DA COSTA, 2014, p. 113115). It seems reasonable that judges should have the instruction and the legal instruments to consider all other sanctions that might have already been applied to the agent in other jurisdictions when deciding about the same illicit behavior. Anti-corruption efforts in these terms would certainly expedite trials, as its legitimacy would be harder to question.

This does not necessarily mean that an agent who has already been punished for a crime cannot also be punished for administrative improbity. Different institutions may positively operate and tackle corruption-related behavior simultaneously. However, judges cannot be entirely indifferent to each other's actions and impacts as they are legitimate representatives of the State sanctioning capacity. Rules that explicitly acknowledge institutional multiplicity and create some degree of coordination between different anti-corruption institutions and agents are needed. Designing such rules and instruments, however, might be challenging as their effectiveness will depend on complex interactions between existing legal, political, as well as economic systems and institutions.

cases, lawsuits involving public servants, public biddings etc. For more information, check: https:// www.tjsp.jus.br/Especialidade/Especialidade/FazendaPublica. 


\section{CONCLUSION}

The Brazilian Administrative Improbity Act created a different kind of punishment for corruption-related behavior, overlapping with other existing sanctions. The new liability regime sought to move away from the established criminal procedure, which is considered slow and burdensome. Contrary to expectations, institutional multiplicity did not result in more effective State action, as these cases have accumulated and were hardly able to recover all the public money diverted from the treasury. The reasons for this might be explained by a combination of poor legal design and implementation problems.

The absence of clear procedural has indeed contributed to curtail the law's effectiveness as defendants were able to postpone final decisions by raising procedural fairness issues. Courts did not manage to respond clearly and promptly to such claims. Decisions extended over multiple trial sessions for several years and precedents in different directions subdued legal certainty, undermining the effectiveness of the new legal mechanism. At least initially, the institutional multiplicity strategy did not result in greater effectiveness and expediency for corruption punishment at any level. Operating within a rather complex political and institutional reality the new law's strategy of promoting institutional multiplicity seems to have backfired.

This paper focused on one legal debate that has occupied Brazilian courts for a long time: the issue of defining the jurisdiction for administrative improbity charges against elected officials and other high-ranking authorities. These cases addressed two sets of problems: (i) whether politicians could be tried before the Judiciary since they were already subject to accountability before the Legislative; and (ii) whether these trials could take place in lower courts, in a potential politically charged atmosphere, or whether these cases should be referred to the Supreme Court. Only recently the Supreme Court reached a final decision on the topic. It empowered anti-corruption authorities, by allowing politicians to be tried for administrative improbity before lower courts, even if the same behavior was also prohibited by other liability regimes. This might expedite administrative improbity suits from now on.

The court took a formalistic legal approach and framed the problem as a matter of defining whether the law should be considered civil, administrative or criminal, so it could decide on the procedural safeguards applicable to such cases. Such problems, however, could have been solved by relatively simple legislative reform, especially if they were framed differently, productively shifting theoretical efforts into pragmatically trying to solve the substantive problems created by the new law. Previous legal experiences from criminal and tax law, for example, suggest that cases could be removed from their natural territorial jurisdiction, allowing defendants to petition for their cases to be tried before one specialized court division in another region if they feel that natural jurisdiction is biased. In addition, judges could be required to explicitly consider all other sanctions that might have already been applied to the defendant in other jurisdictions regarding the same illicit behavior, thus avoiding excessive sanctions. 
The Supreme Court's decision did not address other due process issues such as those regarding the burden of proof or the potential offense to the ne bis in idem principle if one single act gets punished by several different enforcers. Thus, further allegations of procedural fairness regarding other aspects of the statute tend to emerge. A better answer to such problems depends on improving the legal text and devising institutional arrangements that do not eliminate or reduce institutional multiplicity but openly engage in tackling the real problems that might arise from it. This would assist on the development of institutional solutions to enhance anti-corruption efforts as they become less questionable in terms of securing due process and individual rights of the defendants.

\section{REFERENCES}

ASSOCIAÇÃO BRASILEIRA DE JURIMETRIA (ABJ). Radiografia da Improbidade. 2017. Available at: http://naoaceitocorrupcao.org.br/2017/radiografia/ .

ALVES DA SILVA, Paulo Eduardo; HENRIQUES DA COSTA, Susana (coord.). A eficácia do sistema jurídico de prevenção e combate à improbidade administrativa. University of São Paulo, School of Law, Pensando o Direito, n. 34, 2011. Available at: httph://pensando.mj.gov.br/wp-content/uploads/ 2015/07/34Pensando_Direito1.pdf.

ARANTES, Rogério B. The Federal Police and the Ministério Público. In: POWER, Timothy J.; TAYLOR, Matthew M. (ed.). Corruption and Democracy in Brazil: The Struggle for Accountability. Ch. 8. Notre Dame: University of Notre Dame Press, 2011.

ARANTES, Rogério B. O Ministério Público e a corrupção política em São Paulo. In: SADEK, Maria Tereza (org.). Justiça e cidadania no Brasil. Rio de Janeiro: Centro Edelstein, 2009. p. 23-116.

ARANTES, Rogério B. Rendición de cuentas y pluralismo estatal en Brasil: Ministerio Público y Policía Federal. Desacatos, Mexico, n. 49, p. 28-47, Dec. 2015. Available at: http://www.scielo.org.mx/ scielo.php?script $=$ sci_arttext\&pid $=$ S1607-050X2015000300028\&lng $=$ es\&nrm $=$ iso.

BARBÃO, Jaqueline; OLIVEIRA, Fabiana Luci de. Retrato do Cadastro Nacional de Condenados por Ato de Improbidade Administrativa e por Ato que Implique Inelegibilidade (CNCIAI). Revista CNJ, v. 2, p. 24-33, 2017/2018. Available at: http://www.cnj.jus.br/files/conteudo/arquivo/2017/11/ f322d859e3b30d14e4446ec36b4c0e0d.pdf. 
CARDOSO, Evorah; CUSTÓDIO, Rafael; CALDERONI, Vivian; CARVALHO, Sheila de (coord.). Independência funcional e controle interno nas carreiras da Magistratura e do Ministério Público na capital paulista. Série Conectas. Conectas Direitos Humanos: São Paulo, 2016. Available at: https: / /www.conectas.org/ publicacoes/download/independencia-funcional-e-controle-interno-nas-carreiras-da-magistratura-eministerio-publico-na-capital-paulista. Accessed on: January 172019.

CARSON, Lindsey D.; PRADO, Mariana Mota. Using Institutional Multiplicity to Address Corruption as a Collective Action Problem: Lessons from the Brazilian Case. Quarterly Review of Economics and Finance, v. 62, 2016. Available at: https://ssrn.com/abstract $=2885949$.

CONSELHO NACIONAL DE JUSTIÇA (CNJ). Novos diagnósticos do enfrentamento da corrupção. Brasília, May 2012. Available at: http://www.cnj.jus.br/images/pesquisas-judiciarias/Publicacoes/rel_diag_ improbidade.pdf.

DA ROS, Luciano. Accountability legal e corrupção. Revista da CGU, v. 11, n. 20, Brasília, p. 1251 1275, Oct. 2019. Available at: https://repositorio.cgu.gov.br/handle/1/44356.

DAVIS, Kevin. Between Impunity and Imperialism: The Regulation of Transnational Bribery. Oxford: Oxford University Press, 2019.

FERREIRA, Vivian Maria Pereira. A moralidade administrativa e a responsabilização judicial do agente político: um estudo sobre a improbidade administrativa no Brasil. 307p. Doctorate thesis, University of São Paulo, São Paulo, 2020.

FILGUEIRAS, Fernando; AVRITZER, Leonardo. Corrupção e controles democráticos no Brasil. In: CARDOSO JR., José Celso; BERCOVICI, Gilberto (org.). República, democracia e desenvolvimento: contribuições ao Estado brasileiro contemporâneo. Brasília: IPEA, 2013.

GIACOMUZI, José Guilherme. A moralidade administrativa e a boa-fé da administração pública: o conteúdo dogmático da moralidade administrativa. 2. ed. São Paulo: Malheiros, 2013.

GOMES JUNIOR, Luiz Manoel (coord.). Lei de improbidade administrativa: obstáculos a plena efetividade do combate aos atos de improbidade. Brasília: Conselho Nacional de Justiça, 2015. Available at: http: / /www.cnj.jus.br/files/conteudo/arquivo/2018/02/0c9f103a34c38f5b1e8f086ee100809d.pdf.

HOLANDA, Sérgio Buarque de. Raízes do Brasil. 26. ed. São Paulo: Companhia das Letras, 1995 (1936).

LOBO DA COSTA, Regina Helena. Direito administrativo sancionador e direito penal: a necessidade de desenvolvimento de uma política sancionadora integrada. In: BLAZECK, Luiz Maurício Souza; 
MARZAGÃO JÚNIOR, Laerte I. (coord.). Direito Administrativo Sancionador. São Paulo: Quartier Latin, 2014.

MACHADO, Maíra Rocha; PASCHOAL, Bruno. Monitorar, investigar, responsabilizar e sancionar: a multiplicidade institucional em casos de corrupção. Novos Estudos CEBRAP, v. 36, n. 1, p. 11-36, 2016.

MACHADO, Maíra Rocha. Independência como indiferença: ne bis in idem e múltipla incidência sancionatória em casos de corrupção. Direito, Estado e Sociedade, n. 55, 2019.

MACHADO, Maíra Rocha. Crime e/ou improbidade? Notas sobre a performance do sistema de justiça em casos de corrupção. Revista Brasileira de Ciências Criminais, v. 112, p. 189-211, 2015.

MALDONADO, Daniel Eduardo Bonilla. O formalismo jurídico, a educação jurídica e a prática profissional do direito na América Latina. Revista da Faculdade de Direito da UFG, v. 36, n. 2, p. 101 134, Jul.-Dec. 2012.

MARQUES NETO, Floriano de Azevedo; PALMA, Juliana Bonacorsi de. Os sete impasses do controle da administração pública no Brasil. In: PEREZ, Marcos Augusto; SOUZA, Rodrigo Pagani de (coord.). Controle da administração pública. Belo Horizonte: Fórum, 2017. p. 21-38.

MEDINA OSÓRIO, Fábio. Direito administrativo sancionador. 2. ed. São Paulo: Revista dos Tribunais, 2005.

MENDES, Conrado Hübner. Onze ilhas. Folha de S.Paulo, Opinião, Tendências e Debates, 02 / 02/2010. Available at: http://www1.folha.uol.com.br/fsp/opiniao/fz0102201008.htm.

MINISTÉRIO PÚBLICO FEDERAL (MPF). Balanço de 2017 aponta eficiência do MPF no combate à improbidade administrativa. Available at: http: / / www.mpf.mp.br/pgr/noticias-pgr/balanco-de-2017aponta-eficiencia-do-mpf-no-combate-a-improbidade-administrativa.

MINISTÉRIO PÚBLICO FEDERAL (MPF). Relatório de resultados do Procurador-Geral da República: diálogo, unidade, transparência, profissionalismo, efetividade - 2015-2017. Brasília: MPF, 2017. Available at: http: //www.mpf.mp.br/o-mpf/sobre-o-mpf/gestao-estrategica-e-modernizacao-do$\mathrm{mpf} /$ sobre/publicacoes/pdf/relatorio-gestao-pgr-2015-2017.pdf.

MECHANISM FOR FOLLOW-UP ON THE IMPLEMENTATION OF THE INTER-AMERICAN CONVENTION AGAINST CORRUPTION (MESICIC). Federative Republic of Brazil Final Report. Organization of American States (OAS). Washington D.C. September, 2012. Available at: https:// www.oas.org/juridico/PDFs/mesicic4_bra_en.pdf. 
MOISÉS, José Álvaro (coord.). Justiça criminal, impunidade e prescrição: relatório analítico propositivo. Núcleo de Estudos de Políticas Públicas da Universidade de São Paulo e Associação Brasileira de Jurimetria. Brasília: CNJ, 2019.

NEISSER, Fernando Gaspar. A responsabilidade subjetiva na improbidade administrativa: um debate pela perspectiva penal. 313p. Doctorate thesis, University of São Paulo, São Paulo, 2018.

ROSE-ACKERMAN, Susan; PALIFKA, Bonnie J. Corruption and Government: Causes, Consequences and Reform. 2. ed. New York: Cambridge University Press, 2016.

POWER, Timothy J.; TAYLOR, Matthew M. (ed.). Corruption and Democracy in Brazil: The Struggle for Accountability. Notre Dame: University of Notre Dame Press, 2011.

PRADO, Mariana Mota; CARSON, Lindsey D. Brazilian Anti-Corruption Legislation and its Enforcement: Potential Lessons for Institutional Design. IRIBA Working Paper, 9 Jul. 2014. Available at: https: / /ssrn. $\mathrm{com} / \mathrm{abstract}=2497936$.

PRADO, Mariana Mota; CORNELIUS, Eduardo. Institutional Multiplicity and the Fight Against Corruption: A Research Agenda for the Brazilian Accountability Network. Revista Direito GV, v. 16 n. 3, 2020. Available at: https: / /www.scielo.br/pdf/rdgv/v16n3/2317-6172-rdgv-16-03-e1974.pdf.

PRADO, Mariana Mota; PIMENTA, Raquel. Institutional Multiplicity and Systemic Corruption: A Complex Relationship as Illustrated by Brazilian Examples. Unpublished manuscript, 2021.

PÜSCHEL, Flávia Portella; MACHADO, Marta Rodrigues de Assis. Questões atuais acerca da relação entre as responsabilidades penal e civil. In: Anais do CONPEDI - Conselho Nacional de Pesquisa e PósGraduação em direito, Manaus, 2006. Available at: http: / / www.publicadireito.com.br/conpedi/manaus / arquivos/anais/manaus/reconst_da_dogmatica_flavia_puschel_e_marta_machado.pdf. Accessed on: June $3^{\text {rd }} 2020$.

SCHWARCZ, Lilia Moritz. Sobre o autoritarismo brasileiro. São Paulo: Companhia das Letras, 2019.

SILVA, Virgílio Afonso da. O STF e o controle de constitucionalidade: deliberação, diálogo e razão pública. Revista de Direito Administrativo, n. 250, p. 197-227, 2009.

SUNDFELD, Carlos Ari. Direito administrativo para céticos. 2. ed. São Paulo: Malheiros, 2017.

TAYLOR, Matthew M.; BURANELLI, Vinícius C. Ending up in Pizza: Accountability as a Problem of Institutional Arrangement in Brazil. Latin American Politics and Society, v. 49, n. 1, p. 59-87, Spring 2007. 
TEIXEIRA, Adriano; ESTELLITA, Heloísa; CAVALI, Marcelo. Ne bis in idem e o cúmulo de sanções penais e administrativas - um "Estado Hidra de Lerna"? Jota, August 1 ${ }^{\text {st }}$ 2018. Available at: https: / /www.jota.info/ opiniao-e-analise/artigos/ne-bis-in-idem-e-o-cumulo-de-sancoes-penais-e-administrativas-01082018.

TRANSPARENCY INTERNATIONAL. What is Corruption? 2020. Available at: https: / www.transparency. $\mathrm{org} / \mathrm{en} /$ what-is-corruption.

VOJVODIC, Adriana M.; MACHADO, Ana Mara F.; CARDOSO, Evorah. Escrevendo um romance, primeiro capítulo: precedentes e processo decisório no STF. Revista Direito GV, São Paulo, v. 5, n. 1, p. 21-44, 2009.

YIN, Robert. Estudo de caso: planejamento e métodos. 4. ed. Porto Alegre: Bookman, 2010.

WARDE, Walfrido. O espetáculo da corrupção: como um sistema corrupto e o modo de combatê-lo estão destruindo o país. Rio de Janeiro: LeYa, 2018.

\section{HOW TO QUOTE THIS ARTICLE:}

FERREIRA, Vivian Pereira. When Institutional Multiplicity Backfires: The Battle Over the Jurisdiction to Prosecute Politicians for Administrative Improbity in Brazil. Revista Direito GV, São Paulo, v. 17, n. 2, maio/ago. 2021, e2130. https://doi.org/10.1590/2317-

6172202130

\section{Vivian Pereira Ferreira}

LaW degree at University of São Paulo (USP). Master degree (Law and DeVelopment) at São Paulo LaW School (FGV DIREITO SPI. Doctorate degree IN PhILOSOPhy of LAW AT USP.

vivianmpferreiralagmail.com 